\title{
Systematic review of declarative tactical knowledge evaluation tools based on game-play scenarios in soccer
}

\author{
Rubén Sánchez-López $^{1}$ (D ) Ibon Echeazarra ${ }^{1}$ (D) . Julen Castellano ${ }^{1}$ (D)
}

Accepted: 4 July 2021 / Published online: 24 July 2021

(c) The Author(s) 2021, corrected publication 2021

\begin{abstract}
In the last two decades, the analysis of tactical knowledge has become a research channel of increasing interest, contributing to the development of ad-hoc tools to carry out this task. The aim of this study is to collect evaluation tools which allow to measure the declarative tactical knowledge (DTK) in soccer. Five databases (Web of Sciences, Pub Med, SportDiscus, Psycinfo and Eric) were used for the literature search based on PRISMA (Preferred Reporting Items for Systematic Review and Meta-Analyses) guidelines, according to five inclusion/exclusion criteria: (i) tools that determinate DTK in soccer players, (ii) come from primary sources, that is, published for the first time, (iii) show game-play scenarios in video sequences or static images via questionnaires, (iv) have been submitted to a process of validity and reliability, (v) and avoid the use of verbal language. Nine tools were selected and analyzed in this systematic review: Soccer decision-making tests (McMorris, in Percept Mot Ski 85(2):467, 1997), Protocol for the evaluation of declarative tactical knowledge (Mangas, in Conhecimento declarativo no futebol: Estudo comparativo em praticantes federados e não-federados, do escalão de sub-14, Dissertação de Mestrado, Faculdade de Desporto da Universidade do Porto, 1999), Questionnaire for the evaluation of tactical comprehension applied to football—CECTAF-(De la Vega, in Cultura, Ciencia y Deporte, 2002. https://repositorio.uam.es/bitstream/handle/10486/1723/11535_vega_ marcos_ricardodela.pdf?sequence $=1$ ), Decision making instrument for Soccer (Fontana, in The development of a decision making instrument for soccer, Master's degree dissertation, University of Pittsburgh, 2004. http://d-scholarship.pitt.edu/10124/), Game Understanding Test (Blomqvist et al., in Phys Educ Sport Pedagogy 10(2):107-119, 2005), Offensive Football Tactical Knowledge Test-TCTOF-(Serra-Olivares and García-López, in Revista Internacional De Medicina y Ciencias De La Actividad Física y Del Deporte 16(63):521-536, 2016. https://doi.org/10.15366/rimcafd2016.63.008), Video-based decision-making test (Keller et al., in Int J Sports Sci Coach 13(6):1057-1066, 2018. https:// doi.org/10.1177/1747954118760778), Decision-Making form IOS application (Bennett et al., in J Sci Med Sport 22(6):729-734, 2019. https://doi.org/10.1016/j.jsams.2018.12. 011) and TacticUP video test for soccer (Machado and Teoldo, in Front Psychol, 2020. https://doi.org/10.3389/fpsyg.2020.01690). Most of the tools did not pass many of the criteria proposed to assess their quality. Fundamentally, it can be concluded that few tools show specific tactical scores based on game principles or subroles that allow identifying possible points of improvement in the knowledge that players have on specific aspects of
\end{abstract}

Extended author information available on the last page of the article 
the game. For this reason, and based on the other findings found in this review, future studies should consider: (i) the importance of designing tools that reflect scores based on tactical principles and game subroles; (ii) the advantages and disadvantages of designing tools based on static images or video sequences; (iii) the need to design tools that can access the DTK of young children; (iv) the requirement to design tools that present game-play scenarios in the first person; (v) the essentiality of facing the tools designed to rigorous processes of validity and reliability.

Keywords Tactical knowledge · Tactical evaluation · Tactical awareness · Football · Decision-making

\section{Introduction}

Any sport confrontation evolves within a closed field where the actions are channeled inside the borders that space encloses in itself and, beyond this, the game has no meaning (Parlebas 1988). This closed field has a series of characteristics that distinguish and shape it, configuring the possibilities and limitations of action of the players. The way of responding to the problems that the game raises, is not only influenced by this type of constraints, but also by the players' tactical knowledge, which is not inherent to themselves, but is developed and learned (González-Víllora et al. 2015). The players are in constant training, in continuous incorporation of knowledge and experiences, in mutual interaction with each other, and with the physical environment, enriching themselves and enriching the game (Castellano 2000). The mental images that the player must build in the course of the game, which should allow him to read and anticipate the game, are fruit, above all, of the experience, learning and training in contexts of "socio-interaction" (Casamichana et al. 2015), because in team sports, the knowledge the player needs is related to game logic (Gréhaigne et al. 1999).

In the last two decades, the analysis of tactical knowledge has become a research channel of increasing interest, contributing to the development of ad-hoc tools to carry out this task, either from the procedural or declarative level. In the sport field, procedural tactical knowledge (PTK) refers to performance and creation of movements, selecting the most adequate actions according to different competition situations (French and Thomas 1987), being intimately linked to motor action (Kirkhart 2001; Teoldo et al. 2011; Williams and Davids 1995). Specifically, in an eminently open sport with unrepeatable game-play situations such as soccer, PTK should be determined by knowing how, when and where to do it, drawing the "identity document" that determines the traits of the motor action (Parlebas 1993) and the consequences that entails for its realization (Parlebas 2001). Declarative tactical knowledge (DTK) refers to the knowledge on rules, positions, functions, basic offensive and defensive strategies, and understanding of game tactical-technical logic, "to know what to do" (Thomas et al. 1986). It is the player's ability to declare verbally and/or in writing, what is the best decision to be made in a given training or match situation (Tenenbaum and Lidor 2005).

Traditionally, an association has been established between expertise level and declarative tactical knowledge, as it appears that high-skill players possess a larger and more elaborate declarative knowledge base (Williams and Davids 1995). For this reason, selective methodology (Anguera 2003) has traditionally been used to evaluate DTK, and numerous instruments have been designed and validated, allowing access to a large sample, quickly 
and directly, and with little training in its application (Salmon et al. 2009). In this wide range of instruments can be included: The questionnaires on basic knowledge, in terms of terminology, rules, principles of game and performance, used in basketball (Del Villar et al. 2004; French and Thomas 1987; Pinto 1997), volleyball (Moreno-Domínguez et al. 2006), tennis (García-González et al. 2009; McPherson 1987), soccer (Otero et al. 2012), floorball (Contreras Jordán et al. 2005), as well as invasion sports in general (Contreras Jordán et al. 2005; Figueiredo et al. 2008). Verbal protocols based on conditional statements "if ..., then ...", which establish that "if X occurs, then I do Y", which were used for the first time in tennis (McPherson 1987), including later in some of the works mentioned that they value tactical knowledge in other sports; as well as serving as a scaffold for the use of more sophisticated tools through static or dynamic images of game situations. Based on these verbal protocols, tennis interviews have also been conducted, which are subsequently coded according to a system of categories (García-González et al. 2006; McPherson 1999). Interviews with open questions about basic knowledge and tactical problems have been used in soccer (González-Víllora, et al. 2010a, b; Griffin et al. 2001); selfconfrontation interviews (Cranach and Harré 1982) with open-ended questions, carried out after the performance of the participants themselves, have also been used in volleyball (MacQuet 2009), badminton (Macquet and Fleurance 2007), tennis (McPherson and Thomas 1989). Also, interviews through soccer video sequences have been used (Den Hartigh et al. 2018; García-López et al. 2010; González-Víllora et al. 2011, 2013; GonzálezVíllora et al. 2010a, b; Vaeyens et al. 2007). In tennis, in-game interviews have been used to access the knowledge of the participants immediately after the action (McPherson 1987; McPherson and Thomas 1989). The ability to memorize game patterns, associated with the memory paradigm, and related in some way to the anticipatory component in team sports, and therefore to tactical knowledge, was first studied in chess (Chase and Simon 1973), having also been analyzed in soccer (Casanova et al. 2012; McMorris 1997; McMorris and Graydon 1996a, 1996b; Williams et al. 1993). Self-perception questionnaires in invasion sports (Elferink-Gemser et al. 2004) were also used in soccer (Kannekens et al. 2009; Nortje et al. 2014). Reflective supervision protocols have been used through self-reports in basketball (Iglesias 2006). Multi-response tests through iconic images of game situations have been used in soccer (De la Vega 2002; Griffin et al. 2001; McMorris and Graydon 1996a, 1996b; Quina et al. 2011; Serra-Olivares and García-López 2016) and futsal (Souza 2002). Multi-response tests through freezing images of video game sequences have been used in soccer (Bennett et al. 2019; Blomqvist et al. 2005; Fontana 2004; Giacomini et al. 2011; Keller et al. 2018; Machado and Teoldo 2020; Mangas 1999; Praça et al. 2016), tennis (Aburachid et al. 2013) and badminton (Blomqvist et al. 2000). Also, computerized tests based on situations from different sports disciplines have been used (Buscà et al. 2010), computer animations in volleyball (Broek et al. 2011), as well as game simulators in soccer (De la Vega et al. 2008; Helsen and Pauwels 1988; Sánchez-López et al. 2012). The future invites us to think that virtual reality can play a relevant role in the assessment of DTK.

Regarding the limitations found in these tools, one of the key requirements for any tool is that it must be configured from the internal logic of the game (Parlebas 1988), measuring aspects that faithfully constitute the player's soccer competence (Parlebas 2018), both in attack and defense. Furthermore, it seems interesting to go to the operational (Bayer 1979) and core/specific (Castelo 1999; Garganta and Pinto 1994; Hainaut and Benoit 1979; Kunrath et al. 2020; Machado et al. 2020; Queiroz 1983; Teoldo et al. 2009, 2011; Worthington 1974) principles of the game, as well as the roles (Lago 2000) and player subroles (Marqués et al. 2015; Obœuf et al. 2009); since they allow the analysis of the DTK from 
various perspectives, and in relation to the teaching-training processes. Also, an important issue present in the DTK analysis is the role of verbalization in decision-making. Decision making is defined as a choice of action, and it is a result that can be observed as a motor or verbal response (Macmahon and Mcpherson 2009). However, there is no theoretical support to defend the relationship between verbal behavior and tactical behavior (Araújo et al. 2014), so tactical skills and verbalizations about tactical skills cannot be considered equivalent (Araújo et al. 2010). This is because not everything a person says about something is everything he knows about that "something" (De la Vega 2002); since on many occasions, the human being is not able to express everything he knows through language. It is true that, explicit knowledge, in addition to allowing "to do", also allows to explain the reasons and the processes of action (Quina et al. 2011), and verbal protocols have been used to distinguish and compare the mental processes that support the decision-making out of the context of natural play (Petiot et al. 2017), or to measure cognitive effort in perceptionreflection processes (Cardoso et al. 2019). For these reasons, those instruments constructed to access DTK of the players should consider whether to use linguistic competence. Last, ensuring the validity and reliability of the data collected is important for the analysis to fulfil its intentions and purposes effectively (Tenga et al. 2009). Regarding this fact, validity and reliability are two neglected aspects in many tools contemplated in sports literature, and whose importance is essential to ensure a correct evaluation; since validity guarantees that the tool measures what it is intended to measure, while reliability confirms that the tool always measures the same.

Taking this into account, it would be necessary to know if the set of tools analyzed in this review include the above aspects, and to deepen to what extent. Therefore, the primary aim of this review is to present evaluation tools that are able to measure the DTK of soccer players through game-play scenarios without using verbal language, validly and reliably; and the secondary aims are to identify the variables studied by the tools found, evaluate their quality, find the most relevant key aspects that do not comply with the tools presented and justify the design of new tools.

\section{Method}

\subsection{Article search, inclusion and exclusion criteria}

Systematic review about the DTK evaluation tools in soccer from their inception to August 27, 2020; in four phases: identification, screening, suitability and inclusion. In phase 1 (identification), the search strategy was determined and conducted in five databases: Web of Sciences, Pub Med, SportDiscus, Psycinfo and Eric; and in three languages: English, Spanish and Portuguese; according to the following search strategy (Table 1). In this phase, a total of 1,349 studies were found.

In phase 2 (screening), the Mendeley software ${ }^{\circledR}$ was used to organize and manage the search. In this phase, 571 duplicate studies were found and other 701 studies were excluded by reading the title and abstract. A total of 77 potential studies passed this phase.

In phase 3 (suitability), the following inclusion/exclusion criteria was established to select the most interesting tools by reading the full text: (1) the assessment tools had to study variables that determine the DTK in soccer players; (2) had to come from primary sources, that is, published for the first time and discarding adaptations of the original tools; (3) had to show game-play scenarios, either through video sequences or static images in 
Table 1 Search strategy in databases using three languages (English, Spanish and Portuguese)

\begin{tabular}{|c|c|}
\hline Area & Terms \\
\hline \multirow[t]{2}{*}{$\begin{array}{l}\text { Declarative tactical } \\
\text { knowledge }\end{array}$} & $\begin{array}{l}\text { (declarative OR "tactical awareness" OR } \\
\text { "tactical knowledge" OR "tactical evalu- } \\
\text { ation" OR "tactical assessment” OR } \\
\text { "decision making" OR declarativo OR } \\
\text { "conocimiento táctico" OR “compren- } \\
\text { sión táctica" OR "toma de decision" OR } \\
\text { "conhecimento tático" OR "avaliação } \\
\text { tática") }\end{array}$ \\
\hline & AND \\
\hline \multirow[t]{2}{*}{ Sport } & (soccer $\mathbf{O R}$ football $\mathbf{O R}$ fútbol $\mathbf{O R}$ futebol) \\
\hline & AND \\
\hline Tool & $\begin{array}{l}\text { (tool } \mathbf{O R} \text { instrument } \mathbf{O R} \text { test } \mathbf{O R} \text { protocol } \\
\text { OR questionnaire } \mathbf{O R} \text { implement } \mathbf{O R} \\
\text { instrumento OR herramienta } \mathbf{O R} \text { cues- } \\
\text { tionario OR protocol OR teste) }\end{array}$ \\
\hline
\end{tabular}

questionnaires, in which the participant must answer "what to do"; (4) had to have faced a process of validity and reliability, having been published; and (5) could not use "interviews" or "verbal protocols" that expose the participants to explain their answers, knowing that many players are not able to explain everything they know and they do via verbal language. In this phase, the studies were examined in detail by two observers independently, and the kappa correlation index $(k=0.927)$ and the Intraclass correlation coefficient $(I C C=0.95)$ were calculated to establish the degree of agreement between the observers. After this process, the discrepancies found were resolved by consensus. Finally, 71 studies were excluded and six studies (Bennett et al., 2019; Blomqvist et al., 2005; Keller et al., 2018; Machado and Teoldo, 2020; McMorris, 1997; Serra-Olivares and García-López, 2016) exceeded the phase.

In phase 4 (inclusion), three additional studies were included. Two of them were developed in master's degree thesis unpublished (Fontana 2004; Mangas 1999) and the other one in a doctoral thesis also unpublished (De la Vega 2002). These three studies were accessed through references from the 77 potential articles via backward search and were included because all of them met the inclusion/exclusion criteria and present original tools used in published studies in scientific journals. Figure 1 shows the flowchart of the decision taken.

\subsection{Quality of studies and data extraction}

The nine studies that exceeded the inclusion/exclusion criteria were assessed for quality. To obtain a quality score for each study, an ad-hoc checklist was elaborated taking as a reference the criteria used in previous studies (Araújo et al. 2014; Castellano et al. 2014; Chu and Zhang 2018; González-Víllora et al. 2018). A total quality score on a ten-point scale with ten dichotomous questions was calculated. Each item was rated with " 1 " or "0" point (yes $=1$, no $=0$ ), using the criteria established in Table 2 .

The checklist was used by two observers, and any discrepancies were resolved by consensus. In case of doubt, the two main authors debated and agreed on their inclusion. In the event of an agreement not being reached, a third author took part in the decision. Finally, the quality of this systematic review was assessed using the PRISMA (Preferred Reporting Items for Systematic Review and Meta-Analyses) guidelines (Moher et al. 2009). 


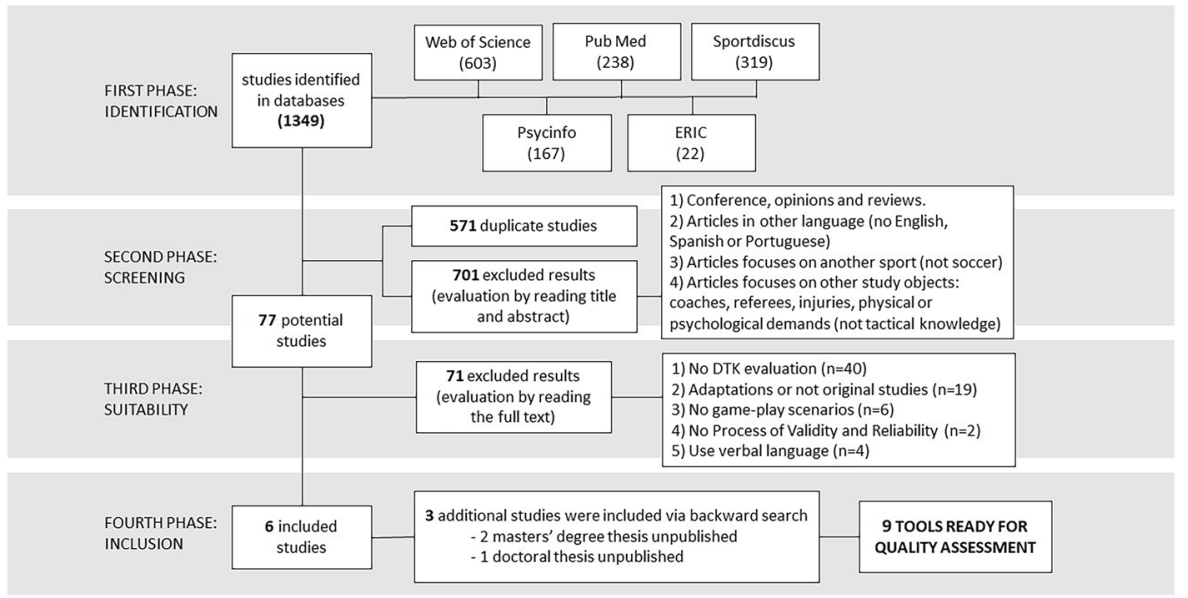

Fig. 1 Flowchart of the decision taken

Table 2 Quality criteria (Q) used to analyze the tools

\begin{tabular}{ll}
\hline Number & Question \\
\hline Q1 & Have the study been published in JCR or SJR? \\
Q3 & Was a sample of players used to test the tool? \\
Q4 & Did the study describe the process of content validity of the tool? \\
Q5 & Did the study describe the process of criterion validity of the tool? \\
Q6 & Did the study describe the process of construct validity of the tool? \\
Q7 & Did the study describe the process of intra-observer stability of the tool? \\
Q8 & Did the study describe the process of inter-observer agreement of the tool? \\
Q9 & Did the study describe the process of internal consistency of the tool? \\
Q10 & Did the study report the procedure to use the tool? \\
Q11 & Does the tool provide an offensive tactical score? \\
Q12 & Does the tool provide a defensive tactical score? \\
Q13 & Does the tool provide scores based on offensive tactical principles? \\
Q14 & Does the tool provide scores based on defensive tactical principles? \\
Q15 & Does the tool provide scores based on offensive game subroles? \\
\hline
\end{tabular}

\section{Results}

\subsection{Summary of the tools}

The articles included in this review are collected in Table 3 where the following categories are described: tool name (author/s, year), tactical variables evaluated, tested with... (sample), process of validity and reliability, and type and number of game-play scenarios. 


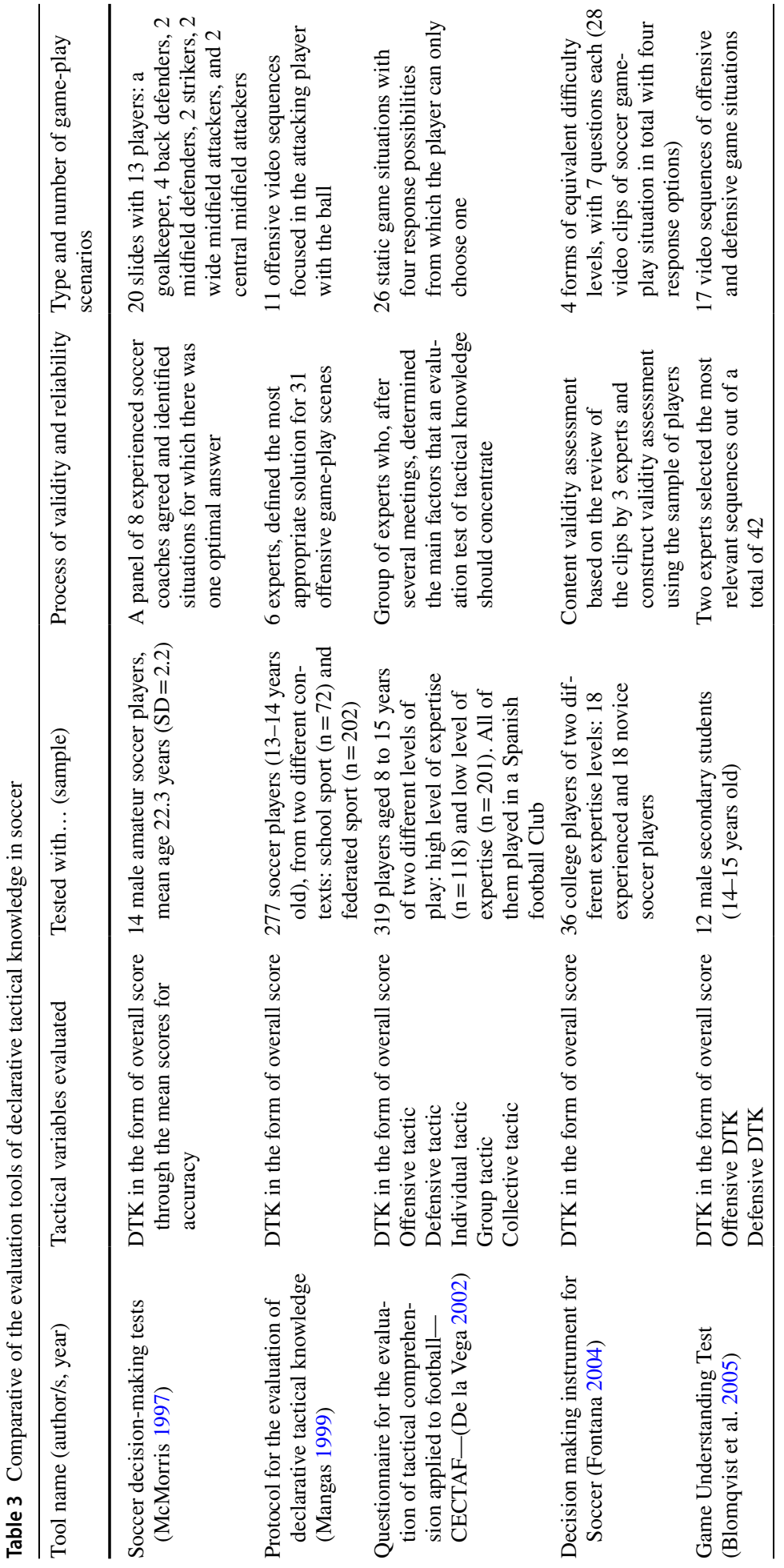




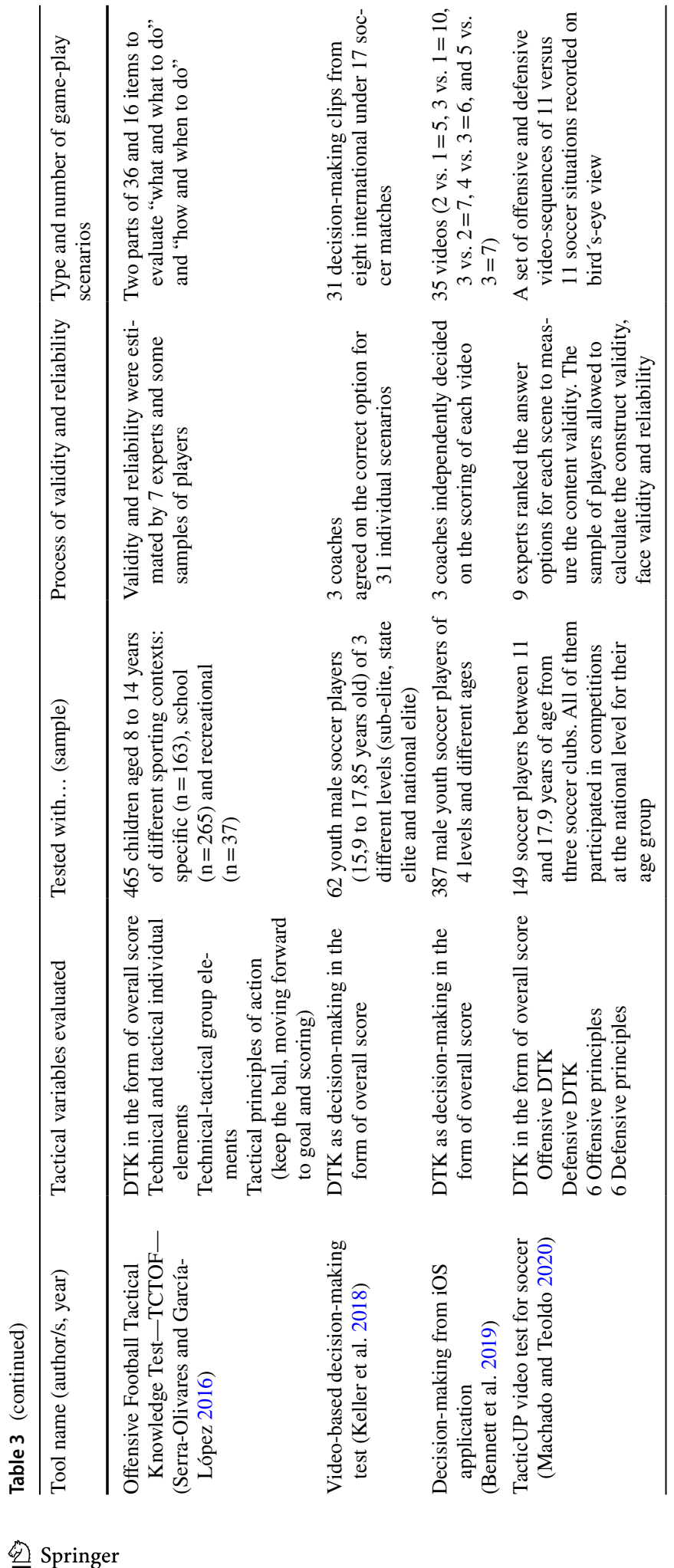




\subsection{Quality of the tools}

Table 4 shows the quality of the tools analyzed. The most relevant results according to the general score were the following: (i) the mean score of the nine selected tools was 6.66 points, (ii) no publication achieved the maximum score of 15 points, (iii) all the tools obtained a score between 5 and 10 points, and (iv) more than half of the sample $(n=6)$ achieved a general score of 5 or 6 points.

More specifically, the following findings can be described: (i) all the studies reported the procedure for using the tools, without going into the rigor and completeness of said process; and the degree of detail of the procedure performed, (ii) the tools were subjected to different validity and reliability processes that are detailed in depth in the discussion of this paper, (iii) all the tools were tested with samples of players, without considering the representativeness of the samples used, (iv) five tools have been published to date in Journal citation report -JCR- or Scimago Journal Rank -SJR-, (iv) all tools provide an offensive tactical score, (v) four tools provide a defensive tactical score, (vi) two tools provide scores based on offensive tactical principles, (vii) a tool provides scores based on defensive tactical principles (viii) none tool studied provides scores based on offensive and defensive game subroles.

\section{Discussion}

The aim of this review was to present evaluation tools that are able to measure the DTK of soccer players through game-play scenarios, validly and reliably.

A total of nine tools were selected and analyzed, considering that 3 of them were not found in databases that collect studies in scientific journals, probably because these tools were validated in doctoral thesis and master's degree thesis of approximately 20 years ago, being used in subsequent studies have been published. The geographic origins of the included tools were: Spain $(n=2)$, Australia $(n=2)$, Brazil $(n=1)$, Portugal $(n=1)$, U.S.A. $(n=1)$, Finland $(n=1)$, and England $(n=1)$. "TacticUP video test for soccer" (Machado and Teoldo 2020) and "TCTOF" (Serra-Olivares and García-López 2016) were the tools with the highest quality score. Therefore, from this review, researchers and coaches are recommended to use these two tools compared to the other tools analyzed. Researchers are also encouraged to create and validate new tools to improve DTK analysis and evaluation based on the findings presented and organized into the following five sections: tactical variables and scores, game scenarios, validity and reliability, limitations and future perspectives.

\subsection{Tactical variables and scores}

An interesting question when evaluating tactical knowledge through tools presented in this study, revolves around which tactical variables are studied and how they are measured. Traditionally, the "game cycle" (Antón 1990) of invading sociomotor sports, such as soccer, has been divided into two directly confronted phases that depend directly on ball possession: the offensive and defensive (Bayer 1986; Malho 1981). In general, all tools $(\mathrm{n}=9)$ provide an offensive tactical score, and four tools present a defensive tactical score (Blomqvist et al. 2005; De la Vega 2002; Machado and Teoldo 2020; Serra-Olivares and 


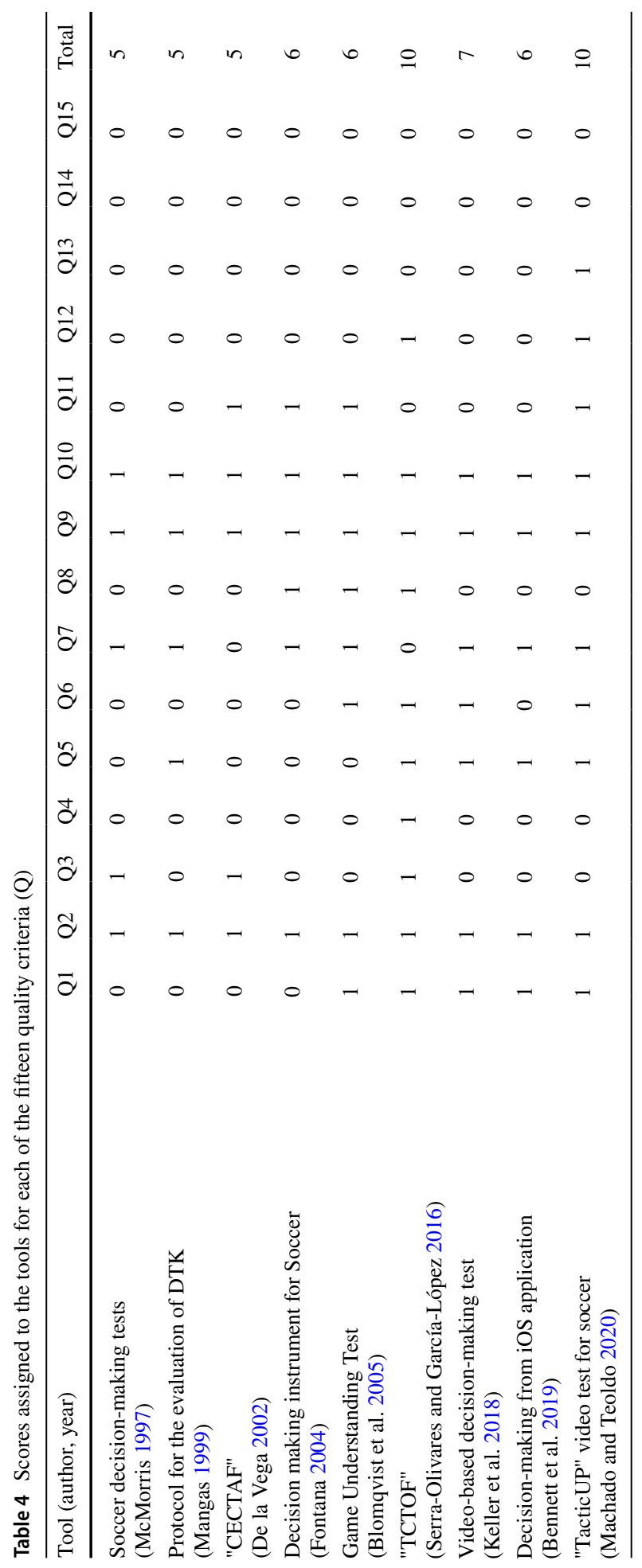


García-López 2016). The possibilities of action of the players, in the offensive and defensive phases, can be framed within the game principles. Tactical principles are defined as a set of norms about the game that provide players with the possibility of rapidly achieve tactical solutions for the problems that arise of the situations they face (Teoldo et al. 2009). The current literature includes various types of game principles: operational principles (Bayer 1979), general/fundamental principles (Garganta and Pinto 1994; Queiroz 1983), core/specific principles (Castelo 1999; Garganta and Pinto 1994; Hainaut and Benoit 1979; Queiroz 1983; Teoldo et al. 2009, 2011; Worthington 1974). Specifically, a tool provides scores based on offensive operational principles (Serra-Olivares and García-López 2016), and another tool provides scores based on offensive and defensive core/specific principles (Machado and Teoldo 2020). This brings benefits, with respect to the other tools, regarding the very specificity of the evaluation of tactical performance in the game context, the attunement with the contents that are developed in the training process and the objectivity of the measure in consideration with the opposition and the evaluation of players of different categories (Teoldo et al. 2011).

The analysis of the sociomotor roles that the players acquire can be interesting to carry out the evaluation of the DTK from another plane, since they allow to classify the participants that take part in the game according to their specific sociomotor status (Parlebas 2001). That is, the set of motor behaviors resulting from the temporary interaction of the ball, player, teammates, opponents and space. However, they do not provide a rigorous and detailed analysis of the game action, for which, it is necessary to go to the subroles associated with each of the game roles (Sánchez-López et al. 2021), since this will serve to appreciate, in the case of each player, the particular orientation that he makes of his role (Lasierra 1993). Subroles are defined as the possible decision behaviors (e.g. pass the ball, shot at goal, make a tackle...) that the player can assume and perform during the development of the game (Hernández Moreno 1995). Regarding this point, no tools studied classifies player performance based on roles, nor does it provide scores based on offensive and defensive game subroles. In no way, this fact suggests that the game-play scenarios presented in each tool do not show images where the subroles that players acquire appear; but they are not analyzed in the form of scores to show the level of knowledge which the participant has about it. Under this idea, obtaining these kinds of scores can be very interesting in order to transport the findings to the teaching and training process.

\subsection{Game-play scenarios: video-sequences vs static game situations}

The main element to configure the game-play scenarios should be the tactical variables presented. Having determined this, one of the questions facing any researcher who tries to design tools to evaluate DTK is the use of game-play scenarios from video sequences or static situations. In this review, six tools used video sequences (Bennett et al. 2019; Blomqvist et al. 2005; Fontana 2004; Keller et al. 2018; Machado and Teoldo 2020; Mangas 1999), while three tools resorted to static game images (De la Vega 2002; McMorris 1997; Serra-Olivares and García-López 2016). Two tools (De la Vega 2002; Serra-Olivares and García-López 2016) based on static game images, were able to access a sample of a younger age (u-8 u-9 and u-10), while all the tools based on video sequences were used with samples above U-11. This is very important when approaching the evaluation of knowledge in the earliest categories, in order to detect possible talents. Also, this finding points to the need to investigate if the different ways of expressing the scenarios to evaluate the DTK could be affected by the age of the players. Another advantage in the use of static 
images compared to video sequences is the ease provided by the questionnaires to reach a larger sample, since the video sequences need a support to project.

Soccer teams are dynamic systems (Garganta and Cunha e Silva 2000), and a static image does not ideally represent what may really be happening in the game situation. For this reason, the use of dynamic film or video may offer a more natural perception of the scene when compared with static slides (Mann et al. 2007). However, the movements can be planned, executed and stored in memory in the form of mental representations (Schack and Tenenbaum 2004), and our brain fails to think about moving images (Damasio 2018). In other words, the brain has the ability to represent aspects (Damasio 2012).

Regarding the personification of the players, two tools based on static images used icons (De la Vega 2002; Serra-Olivares and García-López 2016), and one tool used pictures of soccer players miniatures (McMorris 1997), while three of the tools based on game sequences turned to adult soccer (Fontana 2004; Machado and Teoldo 2020; Mangas 1999), and the other three to formative soccer (Bennett et al. 2019; Blomqvist et al. 2005; Keller et al. 2018). In this sense, the symbolic coding of the images represented in the mind, optimizes the perceptual organization and structuring of the gesture to be performed, at the cognitive level (Díaz Ocejo and Mora Mérida 2009).

Finally, focusing attention on tools based on video sequences, five of them used thirdperson images (Bennett et al. 2019; Blomqvist et al. 2005; Fontana 2004; Keller et al. 2018; Mangas 1999), and one of them bird-eye images (Machado and Teoldo 2020). It would be very interesting to be able to use tools based on first-person video sequences in the future, because they would provide scenarios based on real-world situations, without conditioning participants to perceive information and make decisions differently than they normally would (Roca et al. 2011).

\subsection{Validity and reliability}

To validate this type of instruments, a distinction must be made between content validity, criterion validity and construct validity (Cronbach and Meehl 1955). Content validity reflects a specific content domain of what is measured (Hernández et al. 2010), and is usually calculated through expert judgment. In this review, two instruments (McMorris 1997; Serra-Olivares and García-López 2016) were validated through the independent opinions of a panel of experts, calculating the degree of agreement between them, an instrument (De la Vega 2002) was validated through the expert discussion group technique, another instrument (Bennett et al. 2019) used a set of videos validated in a previous study (Vaeyens et al. 2007), two instruments (Blomqvist et al. 2005; Fontana 2004) were designed without explaining the content validation process, and three instruments (Keller et al. 2018; Machado and Teoldo 2020; Mangas 1999) were developed without describing the content validity process for the selection and adaptation of the scenes that make up the test, although later, groups of experts were used to identify the solutions for the proposed scenes.

Criterion validity, understood as concurrent or concomitant validity, measures the degree of correlation between two measures of the same concept, at the same time and on the same subjects (Polit and Hungler 1999). In other words, the results obtained must be compared with an external criterion that tries to measure the same (Hernández et al. 2010). In one of the seven tools (Serra-Olivares and García-López 2016), the results obtained were correlated with the opinion of the players' coaches who assessed the level of knowledge of their players in a rating scale (0-10), aspect more than questionable due to the subjectivity 
of this process. In the rest of the tools no mention is made of this type of validity. In this sense, it would seem interesting to measure in future studies whether the use of some of the tools presented to the same sample of players provides similar results. Construct validity, from its perspective of discriminant validity (Carvajal et al. 2011), determines the degree of the instrument to distinguish between groups of individuals that are expected to be different (McDowell and Newell 1996), due to their characteristics or performance (Thomas et al. 2011). In two tools (Mangas 1999; Serra-Olivares and García-López 2016), groups were differentiated according to their sports context; in three tools (Bennett et al. 2019; Keller et al. 2018; Machado and Teoldo 2020), groups of different expertise levels were compared considering the quantity of accumulated training hours or the level of the competition. In the studies of the five tools mentioned, the T-Student test (Machado and Teoldo 2020; Mangas 1999; Serra-Olivares and García-López 2016), ANOVA with Tukey Honest Significant Difference post hoc tests (Keller et al. 2018) or Bonferroni post-hoc corrections (Bennett et al. 2019) were used to determine any difference between the groups. This process is not specified in the remaining three tools.

Regarding the reliability of the instruments, three types of reliability were found: intraobserver stability, inter-observer agreement, and internal consistency. For intra-observer stability, four tools (Blomqvist et al. 2005; Keller et al. 2018; Machado and Teoldo 2020; Serra-Olivares and García-López 2016) were subjected to the test-retest correlation, while the measurement of this type of reliability was not specified in the remaining five tools. For inter-observer agreement, in six tools (Bennett et al. 2019; Blomqvist et al. 2005; Keller et al. 2018; Machado and Teoldo 2020; Mangas 1999; McMorris 1997), groups of experts were used to weight, rank or select the possible solutions for each scene; in a tool (Fontana 2004), groups of experienced players were used to carry out this task; while in the other two tools this process is not described. It seems necessary to point out the risk involved in using groups of experienced players in this reliability process, since there is no solid evidence to confirm the relationship between DTK and PTK in professional players. In other words, in professional players, the tactical knowledge acquired can often be implicit, and not explicit. Finally, regarding internal consistency, three instruments (Blomqvist et al. 2005; Fontana 2004; Serra-Olivares and García-López 2016) were analyzed using the cronbach's alpha coefficient. The rest of the instruments do not describe this process.

\subsection{Limitations}

It seems necessary to argue that the limitations of this review are drawn by the inclusion and exclusion criteria used. In this sense, only tools based on game-play scenarios were presented, but there are other types of tools and procedures presented in the introduction of this review that can also be found to approach the evaluation of DTK.

Regarding the decision to avoid the use of verbal language as a means to evaluate DTK, Araújo et al. (2010) point out that, up to now, there is no theoretical support to defend the relationship between verbal behavior and tactical behavior. For this reason, only tools that do not use interviews or verbal protocols have been included in this review, according to one of the criteria presented. On this fact, verbalizing and reflecting about their own performance may help players to become more attuned to important informational constraints that they may encounter in future competitive performance (Silva et al. 2013).

In this way, scientific research continues trying to answer the question that revolves around how declarative and procedural knowledge are related when explaining the tactical performance of players in sociomotor sports (Parlebas 1988) that are characterized by the 
presence of predominantly perceptual skills (Knapp 1963), open skills (Poulton 1957) or externally paced skills (Singer 1980), such as soccer; because there are soccer players who can solve game-specific problems conceptually, but when these problems appear during a practice situation they are unable to apply the same solution; as well as many professional players who do not know how to explain what they are capable of doing, since there is a difference between selecting the answer and executing it in sports compared to selecting the answer and executing it in other domains such as chess; because tactical skills not only involve the ability to determine which decision is most appropriate in a given situation, but involve new decisions if the decision can be successfully executed within the constraints of the required movement (Elferink-Gemser et al. 2010).

\subsection{Future prospects}

Assuming that the analysis of PTK of players, understood as football competence (Parlebas 2018), is especially relevant in football, the evaluation of DTK will also be, as long as there are firm scientific evidences that support the relationship between these two types of knowledge. Therefore, the next step is to determine to what extent this type of tool could be related to tools that evaluate the PTK, for example, the tools presented in the review by González-Víllora et al. (González-Víllora et al. 2015). The existence of a real relationship, would invite to use some of the tools included in this review for the evaluation of DTK in a fast way, accessing speedily to large samples of players. This would allow, among many other things, to evaluate very easily a player longitudinally in time, or transversally with respect to other players, either comparing the player with his teammates (intra-evaluation), or with players from other teams (inter- evaluation). Thus, the conquests, in the form of tactical knowledge, could be detected in each age and category, as well as the particular knowledge that young players show, helping to optimize the teaching and training processes in each specific context and, identifying the keys to success in soccer (LagoBallesteros and Lago-Peñas 2010) and the fundamentals that can support a methodological proposal (Echeazarra 2016). In short, if we understand what children know and how they learn, we will be in a better position to know how to teach (Riera 2005).

\section{Conclusion}

In this systematic review, nine tools were analyzed. "TacticUP video test for soccer" (Machado and Teoldo 2020) and "TCTOF" (Serra-Olivares and García-López 2016) were the tools with the highest quality score. Most of the tools did not pass many of the criteria proposed to assess their quality. Fundamentally, it can be concluded that few tools show specific tactical scores based on game principles or subroles that allow identifying possible points of improvement in the knowledge that players have on specific aspects of the game.

For this main reason, and based on the other findings found in this review, future studies should take into account the following aspects: (i) the importance of designing tools that reflect scores based on tactical principles and game subroles, since this would allow establishing more specific teaching and training processes oriented towards the tactical component of the game, a key aspect in sociomotor sports, such as soccer; (ii) the advantages and disadvantages of designing tools based on static images or video sequences: in general, video sequences can better represent the dynamic reality of the game, but static images allow access to samples from earlier ages; (iii) the need to design tools that can 
access the DTK of young children ( $\mathrm{u}-6, \mathrm{u}-7, \mathrm{u}-8$ ); (iv) the requirement to design tools that present game-play scenarios in the first person, which is what the player can really see in the action; (v) the essentiality of facing the tools designed to rigorous processes of validity and reliability.

Acknowledgements This work was supported by the Spanish government subproject Mixed method approach on performance analysis (in training and competition) in elite and academy sport [PGC2018098742-B-C33] (2019-2021) [“del Ministerio de Ciencia, Innovación y Universidades (MCIU), la Agencia Estatal de Investigación (AEI) y el Fondo Europeo de Desarrollo Regional (FEDER)"], that is part of the coordinated project New approach of research in physical activity and sport from mixed methods perspective (NARPAS_MM) [SPGC201800X098742CV0].

Funding Open Access funding provided thanks to the CRUE-CSIC agreement with Springer Nature.

\section{Declaration}

Conflict of interest The authors declared no potential conflicts of interest with respect to the research, authorship, and/or publication of this article.

Open Access This article is licensed under a Creative Commons Attribution 4.0 International License, which permits use, sharing, adaptation, distribution and reproduction in any medium or format, as long as you give appropriate credit to the original author(s) and the source, provide a link to the Creative Commons licence, and indicate if changes were made. The images or other third party material in this article are included in the article's Creative Commons licence, unless indicated otherwise in a credit line to the material. If material is not included in the article's Creative Commons licence and your intended use is not permitted by statutory regulation or exceeds the permitted use, you will need to obtain permission directly from the copyright holder. To view a copy of this licence, visit http://creativecommons.org/licenses/by/4.0/.

\section{References}

Aburachid, L.M.C., Morales, J.C.P., Greco, P.J.: Test validation process of tactical knowledge in tennis: the influence of practice time and competitive experience. Int. J. Sports Sci. 3(1), 13-22 (2013). https:// doi.org/10.5923/j.sports.20130301.04

Anguera, M.T.: La metodología selectiva en la Psicología del Deporte. In: Hernández Mendo, A. (ed.) Psicología del Deporte, vol. 2, pp. 74-96. EFDeportes (2003)

Antón, J.L.: Balonmano. Gymnos (1990)

Araújo, D., Travassos, B., Vilar, L.: Tactical skills are not verbal skills: a comment on Kannekens and Colleagues. Percept. Mot. Skills 110(3), 1086-1088 (2010). https://doi.org/10.2466/pms.110.C. 1086-1088

Araújo, R., Mesquita, I., Hastie, P.A.: Review of the status of learning in research on sport education: future research and practice. J. Sports Sci. Med. 13(4), 846-858 (2014)

Bayer, C.: L'ensegnement des jeux sportifs collectifs. Vigot. Edc (1979)

Bayer, C.: La enseñanza de los juegos deportivos colectivos. Hispano Eu (1986)

Bennett, K.J.M., Novak, A.R., Pluss, M.A., Coutts, A.J., Fransen, J.: Assessing the validity of a video-based decision-making assessment for talent identification in youth soccer. J. Sci. Med. Sport 22(6), 729734 (2019). https://doi.org/10.1016/j.jsams.2018.12.011

Blomqvist, M., Luhtanen, P., Laakso, L., Keskinen, E.: Validation of a video-based game-understanding test procedure in badminton. J. Teach. Phys. Educ. 19, 325-337 (2000). https://doi.org/10.1123/jtpe.19.3. 325

Blomqvist, M., Vänttinen, T., Luhtanen, P.: Assessment of secondary school students' decision-making and game-play ability in soccer. Phys. Educ. Sport Pedagogy 10(2), 107-119 (2005)

Broek, G.V., Boen, F., Claessens, M., Feys, J., Ceux, T.: Comparison of three instructional approaches to enhance tactical knowledge in volleyball among university students. J. Teach. Phys. Educ. 30(4), 375-392 (2011). https://doi.org/10.1123/jtpe.30.4.375 
Buscà, B., Riera, J., Sevilla, L.G.: Diseño de un nuevo test para evaluar las aptitudes cognitivas en el deporte. Estudio de habilidad y validez. Rev. Psicol. Dep. 19(2), 277-290 (2010)

Cardoso, F., González-Víllora, S., Guilherme, J., Teoldo, I.: Young soccer players with higher tactical knowledge display lower cognitive effort. Percept. Mot. Skills (2019). https://doi.org/10.1177/00315 12519826437

Carvajal, A., Centeno, C., Watson, R., Martínez, M., Sanz Rubiales, Á.: ¿Cómo validar un instrumento de medida de la salud? An. Sist. Sanit. Navar. 34(1), 63-72 (2011). https://doi.org/10.4321/s1137-66272 011000100007

Casamichana, D., San Roman, J., Castellano, J., Calleja-Gonzalez, J.: Los juegos reducidos en el entrenamiento del fútbol. Fútbol De Libro (2015). https://doi.org/10.1519/JSC.0b013e3182548af1

Casanova, F., Garganta, J., Guilherme, J., Williams, M.: Representativeness of offensive scenarios to evaluate perceptual-cognitive expertise of soccer players. Open Sports Sci J. 5, 161-166 (2012). https://doi.org/10.2174/1875399x01205010161

Castellano, J.: Observación y análisis de juego en el fútbol. Universidad del País Vasco, Tesis Doctoral (2000)

Castellano, J., Alvarez-Pastor, D., Bradley, P.S.: Evaluation of research using computerised tracking systems (amisco ${ }^{\circledR}$ and prozone $\left.{ }^{\circledR}\right)$ to analyse physical performance in elite soccer: a systematic review. Sports Med. 44, 701-712 (2014). https://doi.org/10.1007/s40279-014-0144-3

Castelo, J.: Futebol—a organização do jogo. In: Tavares, F. (ed.) Estudos 2 -estudo dos jogos desportivos. Concepções, metodologias e instrumentos, pp. 41-49. Faculdade de Desporto da Universidade do Porto, Multitema (1999)

Chase, W.G., Simon, H.A.: Perception in chess. Cognit. Psychol. 4, 55-81 (1973)

Chu (Alan), T.L., Zhang, T.: Motivational processes in Sport Education programs among high school students: a systematic review. Eur. Phys. Educ. Rev. 24(3), 372-394 (2018). https://doi.org/10. $1177 / 1356336 X 17751231$

Contreras Jordán, O.R., García López, L.M., \& Cervelló Gimeno, E.: Transfer of tactical knowledge from invasion games to floorball. J. Human Movement Stud. (2005). https://www.researchgate.net/ profile/Luis_Garcia_Lopez/publication/235936505_Transfer_of_tactical_knowledge_From_invas ion_games_to_floorball/links/00b7d5149f94ecc82c000000.pdf.

Cranach, M., Harré, R.: The Analysis of Action. Recent Theoretical and Empirical Advances. Cambridge University Press, Cambridge (1982)

Cronbach, L.J., Meehl, P.E.: Construct validity in psychological tests. Psychol. Bull. (1955). https://doi. org/10.1037/h0040957

Damasio, A.: Self Comes to Mind: Constructing the Conscious Brain. Vintage Books, New York (2012)

Damasio, A.: The Strange Order of Things: Life, Feeling, and the Making of Cultures (2018)

De la Vega, R.: Desarrollo del metaconocimiento táctico y comprensión del juego: un enfoque constructivista aplicado al fútbol [Tesis Doctoral. Universidad Autónoma de Madrid]. In: Cultura, Ciencia y Deporte (2002). https://repositorio.uam.es/bitstream/handle/10486/1723/11535_vega_marcos_ ricardodela.pdf? sequence $=1$

De la Vega, R., Del Valle Díaz, M.S., Maldonado Rico, A., Moreno Hernández, A.: Una nueva herramienta para la comprensión táctica en el fútbol. Revista Internacional De Medicina y Ciencias De La Actividad Fisica y Del Deporte 8(30), 130-145 (2008)

Del Villar, F., Iglesias, D., Perla Moreno, M., Fuentes, J.P., Cervelló, E.M.: An investigation into procedural knowledge and decision-making: Spanish experienced-inexperienced basketball players differences. J. Human Movem. Stud. 46, 407-420 (2004)

Den Hartigh, R.J.R., Van Der Steen, S., Hakvoort, B., Frencken, W.G.P., Lemmink, K.A.P.M.: Differences in game reading between selected and non-selected youth soccer players. J. Sports Sci. 36(4), 422-428 (2018). https://doi.org/10.1080/02640414.2017.1313442

Díaz Ocejo, J., Mora Mérida, J.A.: Estrategias representacionales en deportistas: el control de las imágenes como herramienta facilitadora. Contrastes Revista Internacional De Filosofía 16, 91-112 (2009). https://doi.org/10.24310/contrastescontrastes.v0i0.1249

Echeazarra, I.: Un fútbol escaso de fútbol: El formativo. VI Congreso de Deporte en Euskadi. pp. 124133 (2016). https://dialnet.unirioja.es/servlet/articulo?codigo $=7504055$

Elferink-Gemser, M.T., Kannekens, R., Lyons, J., Tromp, Y., Visscher, C.: Knowing what to do and doing it: differences in self-assessed tactical skills of regional, sub-elite, and elite youth field hockey players. J. Sports Sci. 28(5), 521-528 (2010). https://doi.org/10.1080/02640410903582743

Elferink-Gemser, M.T., Visscher, C., Richart, H.C., Lemmink, K.A.P.M.: Development of the tactical skills inventory for sports. Percept. Mot. Skills 99(3), 883-895 (2004). https://doi.org/10.2466/ pms.99.3.883-895 
Figueiredo, L.M., Lago, C., Fernández, M.: Análisis del efecto de un modelo de evaluación recíproca sobre el aprendizaje de los deportes de equipo en el contexto escolar. Motricidad. Revista De Ciencias De La Actividad Física y Del Deporte 21, 102-122 (2008)

Fontana, F.E.: The development of a decision making instrument for soccer. Master's degree dissertation. University of Pittsburgh (2004). http://d-scholarship.pitt.edu/10124/

French, K.E., Thomas, J.R.: The relation off knowledge development to children's basketball performance. J. Sport Psychol. 9, 15-32 (1987). https://doi.org/10.1123/jsp.9.1.15

García-González, L., Perla Moreno, A., Iglesias, D., Moreno, A., Del Villar, F.: El conocimiento táctico en tenis. Un estudio con jugadores expertos y noveles. Cuadernos De Psicología Del Deporte 6(2), 11-20 (2006)

García-González, L., Perla Moreno, M., Moreno-Domínguez, A., Iglesias, D., Del Villar, F.: Estudio de la relación entre conocimiento y toma de decisiones en jugadores de tenis, y su influencia en la pericia deportiva. Int. J. Sport Sci. 17(5), 60-75 (2009)

García-López, L.M., Gutiérrez-Díaz, D., Abellán, J., González-Víllora, S., Webb, L.A.: Expert-novice differences in procedural knowledge in young soccer players from local to international level. J. Human Sport Exerc. 5(3), 444-452 (2010). https://doi.org/10.4100/jhse.2010.53.14

Garganta, J., Cunha e Silva, P.: O jogo de futebol: entre o caos e a regra. Horizonte 91, 5-8 (2000)

Garganta, J., Pinto, J.: O ensino do futebol. In: Oliveira, A., Graça, J. (eds.) O ensino dos jogos desportivos, pp. 95-136. Faculdade de Ciências do Desporto e de Educação Física da Universidade do Porto, Rainho \& Neves Lda (1994)

Giacomini, D.S., Silva, E.G., Greco, P.J.: Comparação do conhecimento tatico declarativo de jugadores de futebol de diferentes categorias e posições. Rev. Bras. Ciênc. Esporte Florianópolis 33(2), 445463 (2011)

González-Víllora, S., García-López, L.M., Gutiérrez-Díaz, D., Contreras-Jordán, O.R.: Estudio descriptivo sobre el desarrollo táctico y la toma de decisiones en jóvenes jugadores de fútbol (12 años). Infancia y Aprendizaje 33(4), 489-501 (2010a). https://doi.org/10.1174/021037010793139644

González-Víllora, S., García-López, L.M., Pastor-Vicedo, J.C., Contreras-Jordán, O.R.: Estudio descriptivo sobre el desarrollo táctico y la toma de decisiones en jóvenes jugadores de fútbol (10 años). Revista De Psicología Del Deporte 20(1), 79-97 (2010b)

González-Víllora, S., García López, L.M., Pastor-Vicedo, J.C., Contreras-Jordán, O.R.: Conocimiento táctico y toma de decisiones en jóvenes jugadores de fútbol (10 años) = Tactical knowledge and decision making in young football players (10 years old). Revista De Psicología Del Deporte 20(1), 79-97 (2011)

González-Víllora, S., García-López, L.M., Gutiérrez-Díaz, D., Pastor-Vicedo, J.C.: Tactical awareness, decision making and skill in youth soccer players (under-14 years). J. Human Sport Exer. 8(2), 412-426 (2013)

González-Víllora, S., Serra-Olivares, J., Pastor-Vicedo, J.C., Teoldo, I.: Review of the tactical evaluation tools for youth players, assessing the tactics in team sports: football. SpringerPlus. 4, 663 (2015). https://doi.org/10.1186/s40064-015-1462-0

González-Víllora, S., Evangelio, C., Sierra-Díaz, J., Fernández-Río, J.: Hybridizing pedagogical models: a systematic review. Eur. Phys. Educ. Rev. 25(4), 1056-1074 (2018). https://doi.org/10.1177/ $1356336 \times 18797363$

Gréhaigne, J.-F., Godbout, P., Bouthier, D.: The foundations of tactics and strategy in team sports. J. Teach. Phys. Educ. 18, 159-174 (1999). https://doi.org/10.1123/jtpe.18.2.159

Griffin, L.L., Dodds, P., Placek, J.H., Tremino, F.: Chapter 4: Middle school students' conceptions of soccer: their solutions to tactical problems. J. Teach. Phys. Educ. 20(4), 324-340 (2001). https:// doi.org/10.1123/jtpe.20.4.324

Hainaut, K., \& Benoit, J.: Enseignement despratiques physiques spécifiques: le football moderne - tactique-technique-lois du jeu. Presses Universitaires de Bruxelles (1979).

Helsen, W.F., Pauwels, J.: The use of simulator in evalutation and training of tactical skills in football. In: T. Really, A. Lees, K. Davids, W.J. Murphy (eds.) Science and Football (pp. 493-497) (1988)

Hernández Moreno, J.: La diversidad de prácticas. Análisis de la estructura de los deportes para su aplicación a la iniciación deportiva. In: D. Blázquez (ed.) La iniciación deportiva y el deporte escolar (pp. 287-310). Inde (1995)

Hernández, R., Fernández, C., Baptista, P.: Metodología de la Investigación. McGraw Hill (2010)

Iglesias, D.: Efecto de un protocolo de supervisión reflexiva sobre el conocimiento procedimental, la toma de decisiones y la ejecución, en jugadores jóvenes de baloncesto. [Tesis doctoral no publicada. Universidad de Extremadura, Cáceres] (2006). https://dialnet.unirioja.es/servlet/tesis?codigo $=562$ 
Kannekens, R., Elferink-Gemser, M.T., Post, W.J., Visscher, C.: Self-assessed tactical skills in elite youth soccer players: a longitudinal study. Percept. Mot. Skills 109(2), 459-472 (2009). https:// doi.org/10.2466/pms.109.2.459-472

Keller, B.S., Raynor, A.J., Iredale, F., Bruce, L.: Tactical skill in Australian youth soccer: does it discriminate age-match skill levels? Int. J. Sports Sci. Coach. 13(6), 1057-1066 (2018). https://doi. org/10.1177/1747954118760778

Kirkhart, M.W.: The nature of declarative and nondeclarative knowledge for implicit and explicit learning. J. General Psychol. 128(4), 447-461 (2001). https://doi.org/10.1080/00221300109598921

Knapp, B.: Skill in Sport-The Attainment of Efficiency. Routledge \& Kegan Paul, London (1963). https://doi.org/10.1080/00140136408956193

Kunrath, C.A., Nakamura, F.Y., Roca, A., Tessitore, A., Teoldo Da Costa, I.: How does mental fatigue affect soccer performance during small-sided games? A cognitive, tactical and physical approach. J. Sports Sci. (2020). https://doi.org/10.1080/02640414.2020.1756681

Lago-Ballesteros, J., Lago-Peñas, C.: Performance in team sports: identifying the keys to success in soccer. J. Hum. Kinet. 25, 85-91 (2010). https://doi.org/10.2478/v10078-010-0035-0

Lago, C.: La acción motriz en los deportes de equipo de espacio común y participación simultánea. [Tesis Doctoral. Universidad de A Coruña] (2000). https://core.ac.uk/download/pdf/61897779.pdf

Lasierra, G.: Análisis de la interacción motriz en los deportes de equipo. Aplicación de los universales ludomotores al balonmano. Apunts Educ Física Deportes 32, 37-53 (1993)

Machado, G.F., González-Víllora, S., Sarmento, H., Teoldo, I.: Development of tactical decision-making skills in youth soccer players: macro- and microstructure of soccer developmental activities as a discriminant of different skill levels. Int. J. Perform. Anal. Sport (2020). https://doi.org/10.1080/24748 668.2020.1829368

Machado, G.F., Teoldo, I.: TacticUP video test for soccer: development and validation. Front. Psychol. (2020). https://doi.org/10.3389/fpsyg.2020.01690

Macmahon, C., Mcpherson, S.L.: Knowledge base as a mechanism for perceptual-cognitive tasks: skill is in the details! Int. J. Sport Psychol. 40(4), 565-579 (2009)

MacQuet, A.C.: Recognition within the decision-making process: a case study of expert volleyball players. J. Appl. Sport Psychol. 21(1), 64-79 (2009). https://doi.org/10.1080/10413200802575759

Macquet, A.C., Fleurance, P.: Naturalistic decision-making in expert badminton players. Ergonomics 50(9), 1433-1450 (2007). https://doi.org/10.1080/00140130701393452

Malho, F.: La iniciación táctica en el juego. Pueblo y Educación (1981)

Mangas, C.J.: Conhecimento declarativo no futebol: Estudo comparativo em praticantes federados e nãofederados, do escalão de sub-14. Dissertação de Mestrado. Faculdade de Desporto da Universidade do Porto (1999)

Mann, D.Y., Williams, A.M., Ward, P., Janelle, C.M.: Perceptual-cognitive expertise in sport: a meta-analysis. J. Sport Exerc. Psychol. 29(4), 457-464 (2007). https://doi.org/10.1123/jsep.29.4.457

Marqués, D., Martínez de Santos, R., Gorostiaga, D.S.: Data quality control of an observational tool to analyze football semiotricity. Cuadernos De Psicología Del Deporte 15(1), 223-232 (2015)

McDowell, I., Newell, C.: Measuring Health: A Guide to Rating Scales and Questionnaires. Oxford University Press (1996)

McMorris, T.: Performance of soccer players on tests of field dependence/independence and soccer-specific. Percept. Mot. Ski. 85(2), 467 (1997)

McMorris, T., Graydon, J.: Effect of exercise on soccer decision-making tasks of differing complexities. J. Hum. Mov. Stud. 30(4), 177-193 (1996a)

McMorris, T., Graydon, J.: The effect of exercise on decision-making performance of experienced and inexperienced soccer players. Res. Q. Exerc. Sport 67, 109-114 (1996b). https://doi.org/10.1080/02701 367.1996.10607933? journalCode=urqe20

McPherson, S.L.: The development of children's expertise in tennis: knowledge structure and sport performance [Doctoral Thesis. Louisiana State University] (1987). https://digitalcommons.lsu.edu/grads chool_disstheses/4409/?utm_source=digitalcommons.1su.edu\%2Fgradschool_disstheses\%2F4409\& utm_medium=PDF\&utm_campaign=PDFCoverPages.

McPherson, S.L.: Expert-novice differences in performance skills and problem representations of youth and adults during tennis competition. Res. Q. Exerc. Sport 70, 233-251 (1999). https://doi.org/10.1080/ 02701367.1999.10608043\#.XzeRtzXtbIU

McPherson, S.L., Thomas, J.R.: Relation of knowledge and performance in boys' tennis: age and expertise. J. Exp. Child Psychol. 48(2), 190-211 (1989). https://doi.org/10.1016/0022-0965(89)90002-7

Moher, D., Liberati, A., Tetzlaff, J., Altman, D.G., Antes, G., Atkins, D., Barbour, V., Barrowman, N., Berlin, J.A., Clark, J., Clarke, M., Cook, D., D’Amico, R., Deeks, J.J., Devereaux, P.J., Dickersin, K., Egger, M., Ernst, E., Gøtzsche, P.C., et al.: Preferred reporting items for systematic reviews and 
meta-analyses: the PRISMA statement. PLoS Med. 6(7), 1-6 (2009). https://doi.org/10.3736/jcim2 0090918

Moreno-Domínguez, A., Perla Moreno, M., Iglesias, D., García, L., Del Villar, F.: Estudio del conocimiento declarativo en función de la experiencia y de la edad en jugadores jóvenes de voleibol. Cultura Ciencia y Deporte 5(2), 73-80 (2006)

Nortje, L., Dicks, M., Coopoo, Y., Savelsbergh, G.J.P.P.: Put your money where your mouth is: verbal selfreported tactical skills versus on-line tactical performance in soccer. Int. J. Sports Sci. Coach. 9(2), 321-334 (2014). https://doi.org/10.1260/1747-9541.9.2.321

Obœuf, A., Collard, L., Pruvost, A., Lech, A.: La prévisibilité au service de l'impré visibilité. À la recherche du « code secret » du football. Reseaux 156(4), 241-270 (2009). https://doi.org/10.3917/res.156.0241

Otero, F.M., González-Jurado, J.A., Calvo-Lluch, Á.: Validación de instrumentos para la medición del conocimiento declarativo y procedimental y la toma de decisiones en el fútbol escolar. Validation tools for measuring procedural and declarative knowledge and assessing decisions in school european footbal. Retos Nuevas Perspectivas De Educación Física, Deporte y Recreación 22, 65-69 (2012)

Parlebas, P.: Elementos de sociología del deporte. Unisport Andalucía (1988)

Parlebas, P.: Didáctica y lógica de las actividades físicas deportivas. Educación Física y Deporte 15(1), 9-26 (1993)

Parlebas, P.: Juegos, Deporte y Sociedad. Léxico de praxiología motriz. Paidotribo (2001)

Parlebas, P.: Une pédagogie des compétences motrices. Acciónmotriz 20, 89-96 (2018)

Petiot, G.H., Aquino, R., Cardoso, F., Santos, R., Teoldo, I.: What mental process favours quality decision-making in young soccer players? Motriz: Revista De Educação Física (2017). https://doi.org/ 10.1590/s1980-6574201700030003

Pinto, D.: Construção de um teste para avaliar o conhecimento declarativo no jogo. In: A. Marques, A. Prista \& A. Júnior (Eds.), Educação Física: contexto e inovação. Actas do V congresso de Educação Física e Ciências do Desporto dos países de língua Portuguesa, 24-28 Março 1997: Vol. II (pp. 337-348) (1997)

Polit, D., Hungler, B.: Nursing research: principles and methods. JB Lippincott \& Co., Philadelphia (1999)

Poulton, E.C.: On prediction in skilled movements. Psychol. Bull. 54, 467-478 (1957). https://doi.org/ $10.1037 / \mathrm{h} 0045515$

Praça, G.M., Lopes, M., Pérez-Morales, J.C., Greco, P.J.: Teste de conhecimento declarativo no futebol: TCTD:Fb2: validação preliminar. Revista De Educação Física Do Exército 85(2), 199 (2016)

Queiroz, O.: Para uma teoria do ensino/treino do Futebol. Futebol Em Revista 4(1), 47-49 (1983)

Quina, J., Camões, M., Graça, A.: Desenvolvimento e validação de um instrumento de avaliação do conhecimento tático em futebol (2011). https://bibliotecadigital.ipb.pt/handle/10198/6996

Riera, J.: Habilidades en el deporte. Inde (2005)

Roca, A., Ford, P.R., McRobert, A.P., Williams, A.M.: Identifying the processes underpinning anticipation and decision-making in a dynamic time-constrained task. Cogn. Process. 12, 301-310 (2011). https://doi.org/10.1007/s10339-011-0392-1

Salmon, P., Stanton, N.A., Gibbon, A., Jenkins, D., Walker, G.H.: Human factors methods and sports science. In: Human Factors Methods and Sports Science. CRC Press (2009). https://doi.org/10. $1201 / 9781420072181$

Sánchez-López, R., De la Vega, R., Ruíz-Barquín, R., Del Valle Díaz, M.S.: Análisis y evaluación de los niveles de toma de conciencia y comprensión táctica en fútbol por medio de un tablero de juego. SPORT TK-Revista EuroAmericana De Ciencias Del Deporte 1(1), 33-38 (2012). https://doi.org/ 10.6018/185481

Sánchez-López, R., Echeazarra, I., Castellano, J.: Validation of a football competence observation system (FOCOS), linked to procedural tactical knowledge. Sustainability 13(12), 6780 (2021). https:// doi.org/10.3390/su13126780

Schack, T., Tenenbaum, G.: Effect representation and action planning: a preface. Int. J. Sport Exercise Psychol. 2, 343-345 (2004). https://doi.org/10.1080/1612197x.2004.9671749

Serra-Olivares, J., García-López, L.M.: Design and validation of the soccer tactical knowledge test (STKT)/Diseño y validación del test de conocimiento táctico ofensivo en fútbol (TCTOF). Revista Internacional De Medicina y Ciencias De La Actividad Física y Del Deporte 16(63), 521-536 (2016). https://doi.org/10.15366/rimcafd2016.63.008

Silva, P.M., Garganta, J., Araújo, D., Davids, K., Aguiar, P.: Shared knowledge or shared affordances? Insights from an ecological dynamics approach to team coordination in sports. Sports Med. 43, 765-772 (2013). https://doi.org/10.1007/s40279-013-0070-9

Singer, R.N.: Motor learning and human performance. McMillan (1980). https://doi.org/10.1016/j.iilr. 2013.06.001 
Souza, P.: Validação de Teste para avaliara a capacidade de decisão táctica e o conhecimento declarativo em situações de ataque no futsal. Tese de Mestrado, Universidade Federal de Minas Gerais (2002)

Tenenbaum, G., Lidor, R.: Research on decision-making and the use of cognitive strategies in sport settings. In: Hackfort, D., Duda, J., Lidor, R. (eds.) Handbook of Research in Applied Sport and Exercise Psychology: International Perspectives, pp. 75-91. WV, Morgantown (2005)

Tenga, A., Kanstad, D., Ronglan, L.T., Bahr, R.: Developing a new method for team match performance analysis in professional soccer and testing its reliability. Int. J. Perform. Anal. Sport 9(1), 8-25 (2009). https://doi.org/10.1080/24748668.2009.11868461

Teoldo, I., Garganta, J., Greco, P.J., Mesquita, I.: Tactical principles of soccer: concepts and application tactical principles of soccer. Motriz, Rio Claro 15(3), 657-668 (2009). https://doi.org/10.5016/2488

Teoldo, I., Garganta, J., Greco, P.J., Mesquita, I.: Proposta de avaliação do comportamento tático de jogadores de futebol baseada em princípios fundamentais do jogo. Motriz: Revista De Educação Física 17(3), 511-524 (2011). https://doi.org/10.1590/S1980-65742011000300014

Thomas, J.R., French, K.E., Humphries, C.A.: Knowledge development and sport skill performance: directions for motor behavior research. J. Sport Psychol. 8(4), 259-272 (1986). https://doi.org/10.1123/ jsp.8.4.259

Thomas, J.R., Nelson, J., Silversman, S.: Research methods in physical activity. Human Kinetics (2011)

Vaeyens, R., Lenoir, M., Williams, A.M., Mazyn, L., Philippaerts, R.M.: The effects of task constraints on visual search behavior and decision-making skill in youth soccer players. J. Sport Exerc. Psychol. 29(2), 147-169 (2007). https://doi.org/10.1123/jsep.29.2.147

Williams, M., Davids, K.: Declarative knowledge in sport: a by-product of experience or a characteristic of expertise? J. Sport Exerc. Psychol. 17(3), 259-275 (1995). https://doi.org/10.1123/jsep.17.3.259

Williams, M., Davids, K., Burwitz, L., Williams, J.: Cognitive knowledge and soccer performance. Percept. Mot. Skills 76(2), 579-593 (1993). https://doi.org/10.2466/pms.1993.76.2.579

Worthington, E.: Learning \& Teaching Soccer Skills. Publ. Melvin Powers, Wilshire Book Company, Bakewell (1974)

Publisher's Note Springer Nature remains neutral with regard to jurisdictional claims in published maps and institutional affiliations.

\section{Authors and Affiliations}

\section{Rubén Sánchez-López $^{1}$ (D) Ibon Echeazarra ${ }^{1}$ (D) Julen Castellano ${ }^{1}$ (D)}

Rubén Sánchez-López

ruben.football@gmail.com

Ibon Echeazarra

ibon.etxeazarra@ehu.eus

Julen Castellano

julen.castellano@ehu.eus

1 Physical Education and Sport, University of the Basque Country, Vitoria, Spain 